Volume 3 No. 1, Juni 2018

P ISSN 2442-594X | E ISSN 2579-5708

http://journal.iainlangsa.ac.id/index.php/tibyan

DOI: 10.32505/tibyan.v3i1.473

\title{
KEMUKJIZATAN PSIKOLOGI ALQURAN JAMAAH MAJELIS TAKLIM (Studi Kasus di Kecamatan Bogor Selatan Bogor)
}

\author{
The Miracle of Psychology of Qur'an in Majlis Taklim's Members \\ (Case Study in South Bogor District, Bogor)
}

\author{
Ali Thaufan Dwi Saputra \\ UIN Syarif Hidayatullah Jakarta \\ alitopands@gmail.com
}

\begin{abstract}
The author's main concern in this research is to study the miracles of Alquran and psychology of religion. Several theories in this study are used to see the equanimity after reciting and listening to the Quran in members of three majelis taklimslocated in Bogor Selatan District, Bogor City. This research uses qualitative method and adopts the approachof psychology. The bibliographic data (primary books on the miracles of Alquran and psychology) and field (interview, questionnaire) are used to analyze the psychological miracles of the majelis taklim members. Academically, this study can complement the existing books that discuss the miracles of Alquran. In terms of the science of Alquran, this study affirms the existence of miracles in Alquran, and the psychological effects on the reciter. While psychologically, this study wants to show that the holy book - in any religion - is very important to its adherents. In the end, this study would like to prove that the the members of majelis taklim who read and hear the Quran will feel the peace and tranquility of the soul. Furthermore, reciting and listening to the Quran will not only gives peace to the soul, but can increase faith and implicate the conduct of worshipers such as prayers and infak. The result of this study shows that after reading the Alquran, the members of majelis taklim feel the calm. However, the implications for an increase in faith involving congregational prayer and giving infak very fluctuational (unstable). It can be introduced that one's faith can indeed increase and decrease (yazdâd wa yankus).
\end{abstract}

Keywords:Miracles, Members, Majelis Taklim

\begin{abstract}
Abstrak
Perhatian utama penulis dalam penelitian ini adalah mengkaji kemukjizatan alQur'an dan ilmu jiwa (psikologi) agama. Beberapa teori dalam kajian tersebut penulis gunakan untuk melihat adanya pengaruh ketenangan jiwa setelah membaca dan mendengar al-Qur'an pada jamaah ditiga majelis taklim yang terletak di Kecamatan Bogor Selatan Kota Bogor. Penelitian ini menggunakan metode kualitatif dengan menggunakan pendekatan psikologis. Data-data kepustakaan (buku-buku primer tentang kemukjizatan al-Qur'an dan ilmu psikologi) dan lapangan (wawancara, observasi dan angket) penulis gunakan
\end{abstract}


untuk menganalisa psikologi terhadap jamaah majelis taklim. Pada akhirnya, penelitian ini ingin membuktikan bahwa para jamaah yang membaca dan mendengar Alquran akan merasakanketenangan dan ketentraman jiwa. Selanjutnya, membaca dan mendengar Alquran tidak hanya memberi ketenangan jiwa, tetapi dapat meningkatkan iman dan berimplikasi pada perilaku keagamaan para jamaah seperti: sala dan, infak. Hasil penelitian ini menunjukkan bahwa setelah membaca Alquran, para jamaah merasakan ketenangan. Namun implikasi pada peningkatan iman yang ditunjukkan dengan intensitas salat berjamaah dan berinfak sangat fluktuatif (tidak stabil). Hal ini dapat dipahami bahwa keimanan seseorang memang dapat bertambah dan berkurang (yazdâd wa yankus).

Kata Kunci:Kemukjizatan, Jamaah, Majelis Taklim.

\section{Pendahuluan}

Perkembangan zaman yang diiringi dengan kompleksitas kehidupan membuat manusia selalu berusaha mencari ketenangan dan kebahagiaan hidup. Sebagai kitab suci, Alquran diyakini dapat memberikan dampak yang positif, yakni memberi ketenangan, kepuasan dan pengalaman spiritual dalam kehidupan manusia, terutama umat Islam. Tetapi, membaca Alquran semata tidaklah cukup. Pembaca juga harus memahami, menemukan kandungan ayat dan mengamalkan isi kandungan tersebut. Muhammad al-Ghazali ${ }^{1}$ menyarankan agar umat Islam berupaya memahami Alquran. Ia bahkan mengkritik seseorang yang hanya sebatas membaca Alquran tanpa menggali nilai-nilai yang terkandung di dalamnya. ${ }^{2}$

Pembelajaran Alquran untuk memahami isi kandungan baik yang formal maupun non formal sangat banyak dan mudah ditemui. Salah satunya adalah melalui majelis taklim, pengajian rutin yang jamaahnya terdiri baik laki-laki maupun perempuan (meski umumnya didominasi kaum perempuan). Keberadaan sebuah majelis taklim amat penting karena melalui majelis tersebut, transformasi wawasan Alquran disampaikan. Itulah sebabnya penting bagi penulis untuk melakukan penelitian berkenaan dengan "posisi" Alquran bagi jamaah majelis taklim.

Secara akademik penelitian ini dapat melengkapi buku-buku yang membahas kemukjizatan Alquran dan menguatkan buku "Mukjizat Alquran: Di tinjau dari Aspek Kebahasaan, Isyarat Ilmiah dan Pemberitaan Ghaib" karya M. Quraish Shihab. Dalam buku tersebut, ia memaparkan adanya kemukjizatan psikologis bagi siapapun yang mendengar dan membaca Alquran, yaitu ketenangan yang dirasakan pembacanya. Selain itu, penelitian ini juga dapat menjadi masukan bagi pihak-pihak penyelenggara majelis taklim agar merumuskan metode belajar Alquran dengan baik, sehingga cita-

\footnotetext{
${ }^{1}$ Ia seorang ulama yang ahli dalam berbagai bidang keilmuan. Lahir pada 22 Septerber 1917 di Mesir dan wafat pada 9 Maret 1996. Banyak karya dan buku-buku yang telah dihasilkan, termasuk yang berkaitan dengan Alquran dan ilmu tafsir, antara lain: Kaifa Nata'amal ma'a Alquran, Nahwa Tafsir Maudhû'î li Suwar Alquran al-Karîm, Al-Mahâwir al-Khamsah lî Alquran al-Karîm dan Nadharât fi Alquran.

${ }^{2}$ Muhammad al-Ghazali, Kaifa Nata’amal ma’a Alquran, (Kairo: Nahdetmisr, 2005), h. 29
} 
cita mencetak generasi Qur'ani dapat tercapai melalui kelompok-kelompok pengajian seperti majelis taklim.

Dilihat dari segi ulûm al-Qur'ân, penelitian ini menegaskan adanya kemukjizatan dalam Alquran, dan pengaruhnya terhadap psikologis pembaca. Sedangkan dari segi ilmu psikologi, penelitian ini juga ingin menunjukkan bahwa kitab suci -dalam agama apa saja- sangat penting bagi pemeluknya. Ia adalah pedoman yang membimbing pemeluk suatu agama tertentu. Sedangkan dilihat dari segi pengelolaan majelis taklim, penelitian ini dapat menjadi referensi pada stakeholderuntuk meningkatkan mutu pengajaran Alquran pada majelis taklim.

Penelitian ini dilakukan di tiga majelis taklim yang berada di Kecamatan Bogor Selatan Kota Bogor. Pemilihan majelis taklim adalah rekomendasi dari Kantor Urusan Agama (KUA) dengan mempertimbangkan tingkat keaktifan kegiatan pengajian. Berkenaan dengan metode, penulis menggunakan metode penelitian kualitatif, dengan menggunakan pendekatan psikologis. Penulis memaparkan hubungan membaca Alquran jamaah majelis taklim terhadap ketenangan jiwa para jamaah majelis taklim serta pengaruhnya dalam perilaku keseharian.

Teknik pengumpulan data pada penelitian ini dilakukan antara lain dengan: studi pustaka, ${ }^{3}$ observasi, ${ }^{4}$ wawancara, ${ }^{5}$ angket, ${ }^{6}$ dan dokumentasi. ${ }^{7}$ Dalam proses pengisian, penulis dibantu oleh para pengurus majelis taklim. Hal ini dilakukan guna memermudah komunikasi karena keterbatasan penulis berbahasa Sunda. Penulis menggunakan metode pengumpulan data melalui observasi, wawancara dan angket karena metode tersebut lazim digunakan dalam penelitian yang menggunakan pendekatan psikologis. ${ }^{8}$

${ }^{3}$ Teknik ini dilakukan dengan pengumpulan dataserta analisa-analisa bacaan yang memiliki hubungan dan kaitan dengan pokok pembahasan penulis, dengan tujuan memperoleh data-data primer dan sekunder.Adapun sumber-sumber bacaan meliputi buku-buku ilmu-ilmu Alquran (kemukjizatan Alquran), ilmu psikologi, ilmu dakwah dan ilmu sosial.

${ }^{4}$ Kegiatan observasi ini dilakukan untuk melihat langsung proses belajar mengajar Alquran dalam suatu majelis taklim, serta melihat perilaku jamaah di luar lingkungan majelis.

${ }^{5}$ Penulis menggunakan metode ini untuk menggali informasi terkait perkembangan majelis taklim di wilayah Kecamatan Bogor Selatan. Selain itu, metode ini digunakan untuk menggali informasi atau untuk mendapat data-data majelis taklim yang akan diteliti.

${ }^{6}$ Melalui teknik ini, penulis memberi beberapa pertanyaan kepada para jamaah majelis taklim yang dilakukan dalam dua tahap. Tahap pertama dilakukan pada bulan Juni 2015, dan tahap kedua dilakukan pada bulan November 2015. Teknik ini dimaksudkan untuk menggali informasi seputar motivasi yang mendasari keinginan jamaah belajar membaca Alquran; bagaimana cara jamaah memahami kandungan ayat Alquran; serta adakah rasa ketenangan hati dan jiwa setelah membaca Alquran sehingga berimplikasi pada keimanan. Jenis angket yang penulis gunakan adalah angket tertutup tetapi ada pula pertanyaan yang terbuka. Seperti dijelaskan Bagong Suryanto, terdapat 3 jenis angket, tertutup, terbuka dan semi terbuka. Pertama, tertutup, yakni angket yang disertai pertanyaan tetapi responden hanya memilih jawaban yang telah disediakan. Kedua terbuka, yakni angket yang jawabannya ditulis sendiri oleh responden. Ketiga, semi terbuka, yakni angket yang selain diberi jawaban, responden juga diberikan kesempatan alternatif jawaban dengan mengisi sendiri. Bagong Suryanto-Sutinah (ed), Metode Penelitian Sosial: Berbagai Alternatif Pendekatan, (Jakarta: Kencana Prenada Media Group, 2005), h. 64

${ }^{7}$ Data-data seperti rekaman, foto dan catatan penulis juga digunakan dalam penelitian ini.

${ }^{8}$ Abdul Rahman Saleh, Psikologi: Suatu Pengantar dalam Perspektif Islam, (Jakarta: Kencana Prenada Media Grup, 2008), h. 41 
Adapun analisis data dilakukan dengan menggunakan teknik analisa data berlangsung dan mengalir (flow model analisis). Untuk menggunakan model analisis ini, penulis melakukan empat tahapan, yakni: pengumpulan data, reduksi data, display data dan verifikasi atau menarik kesimpulan.

\section{Memahami Posisi Alquran Bagi Pembacanya}

Membaca Alquran, menggali isi kandungan serta mengamalkan dalam kehidupan praktis merupakan ibadah mendekatkan diri kepada Allah. Hal ini dimaksudkan guna mendapat ketenangan dalam hidup. Alquran sebagai mukjizat memberikan isyarat bagi seseorang yang mengingat Allah, niscaya mendapat ketenangan. ${ }^{9}$ Keterangan ini terkonfirmasi sebagaimana termaktub dalam Sûrah al-Ra'd: 28

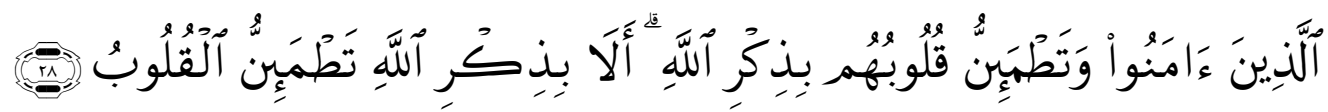

Artinya: “(yaitu) orang-orang yang beriman dan hati mereka menjadi tenteram dengan mengingat Allah. Ingatlah, hanya dengan mengingat Allah, hati menjadi tenteram". (Q.S. al-Rad [13]: 28) ${ }^{10}$

Menurut al-Zamakhsyarî, ketenteraman atau ketenangan dalam hati dapat tercapai dengan beriman dan senantiasa mengingat Allah serta berzikir. Ketenangan juga dapat dicapai dengan membaca Alquran karena Alquran adalah mukjizat yang menenangkan hati dan memantapkan keyakinan seseorang. ${ }^{11}$

Sementara menurut Quraish Shihab, bahwa redaksi Alquran yang cukup indah diyakini dapat memberikan rasa tenteram. Lebih lanjut, Shihab menjelaskan bahwa kata (بِنِكْرِ) dapat berarti menyebut kebesaran, perintah, larangan dan wahyu Allah. Selain itu pada ayat di atas juga dijelaskan bahwa al-Dzikr tidak hanya berarti mengingat, tetapi juga berarti Alquran. Pendapat tersebut didasarkan pada nama-nama lain Alquran, yakni al-Dzikr. ${ }^{12}$ Ayat serupa juga terdapat pada QS. al-Zumar: 23.

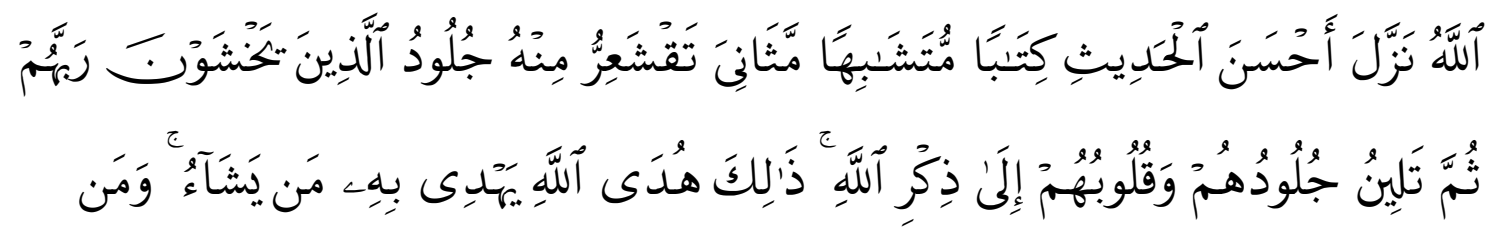
h. 76 .

${ }^{9}$ Muhammad Tholchah Hasan, Dinamika Kehidupan Religius, (Jakarta: Listafariska Putera, 2000),

${ }^{10}$ Terjemah ayat di atas penulis kutip dari Alquran dan Terjemahnya yang diterbitkan Departemen Agama RI Tahun 2006. Pada ayat-ayat berikutnya penulis juga merujuk pada Alquran yang diterbitkan Departemen Agama tersebut.

${ }^{11}$ Abû Qasim Mahmud ibn Umar al-Zamakhsyarî, al-Kasysyâf 'An Haqâiqi Ghamâmi al-Tanzîl wa 'Uyûn al-Aqawîl fî̀ Wujûh al-Ta'wîl, (Beirut: Dâr al-Kutub al-'Alamiyah, 2009), vol. 2, h. 508

${ }^{12}$ M. Quraish Shihab, Tafsir Al-Misbah: Pesan, Kesan dan Keserasian Alquran, (Jakarta: Lentera Hati, 2002), vol. 6, h. 587. Dalam menafsirkan ayat di atas, Ibn Abbas menafsirkan kata al-Dzikr yang berarti Alquran. Lihat: Abî Thâhir ibn Ya'qûb al-Fairuzi Abadi, Tanwîr al-Mu'bâs min Tafsîr Ibn Abbâs, (Bairut: Dâr al-Fikr, 2001), h. 253 


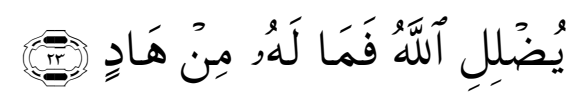

Artinya: "Allah telah menurunkan perkataan yang paling baik (yaitu) Al Quran yang serupa (mutu ayat-ayatnya) lagi berulang-ulang, gemetar karenanya kulit orang-orang yang takut kepada Tuhannya, kemudian menjadi tenang kulit dan hati mereka ketika mengingat Allah. Itulah petunjuk Allah, dengan kitab itu Dia memberi petunjuk kepada siapa yang Dia kehendaki. Dan barangsiapa yang dibiarkan sesat oleh Allah, maka tiadakan seorang pun yang dapat memberi petunjuk" (QS. Al-Zumar [39] : 23).

Selain ayat Alquran, terdapat beberapa hadis nabi yang menerangkan ketenangan hati pembaca Alquran, diantaranya seperti diriwayatkan Abu Daud;

Artinya: "Dari Abu Hurairah berkata bahwa Rasulullah bersabda, 'Tidaklah suatu kaum berkumpul di salah satu rumah dari rumah-rumah Allah, mereka membaca kitab Allah dan saling mengajarkannya di antara mereka, melainkan diturunkan ke atas mereka sakinah, rahmat menyirami mereka, para malaikat mengerumuni mereka, dan Allah menyebut mereka di kalangan (malaikat) yang ada disisinya.""13

Ketenteraman dan ketenangan bagi seorang hamba yang senantiasa mengingat Allah ditandai dengan kembalinya ia kepada Allah semata, yaitu kembali kepada Allah dengan ridha dan ikhlas karenaNya. Alquran menerangkan dalam QS. al-Fajr: 27-28.

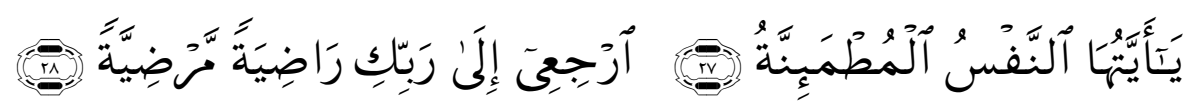

Artinya: "Wahai jiwa yang tenang. Kembalilah kepada Tuhanmu, dengan hati yang ridha dan diridhaiNya" (Q.S. al-Fajr [89] :27-28).

Ketenangan hati bagi seseorang ibarat sebuah kebutuhan. Setiap orang mendambakan ketenangan dan ketentraman hati. Berbagai cara atau metode dilakukan untuk mencapai ketenangan. Ketenangan hati hanya didapat bagi seseorang yang terus berusaha meniadakan dorongan nafsu dalam hatinya serta berupaya membersihkannya (hati). Cara paling mudah dalam mencapai ketenangan hati adalah dengan mendekatkan diri kepada Allah. ${ }^{14}$ Selain ketenangan hati yang didapat setelah membaca Alquran, Allah juga menerangkan bahwa dengan membaca Alquran, keimanan seseorang dapat bertambah. Dalam QS. al-Anfâl: 2-3 Allah berfirman:

${ }^{13}$ Abî Dâud Sulaimân ibn al-Asy'ats al-Sijistani, Sunan Abî Dâud, (Beirut: Dâr al-Kitab al-'Arabi, tt), vol. 1, h. 544

${ }^{14}$ Abd Syakur, "Metode Ketenangan Jiwa (Suatu Perbandingan Antara al-Ghazali dan Sigmund Freud)", dalam Jurnal Islamica, Vol. 1, No. 2, Maret 2017, h. 172 


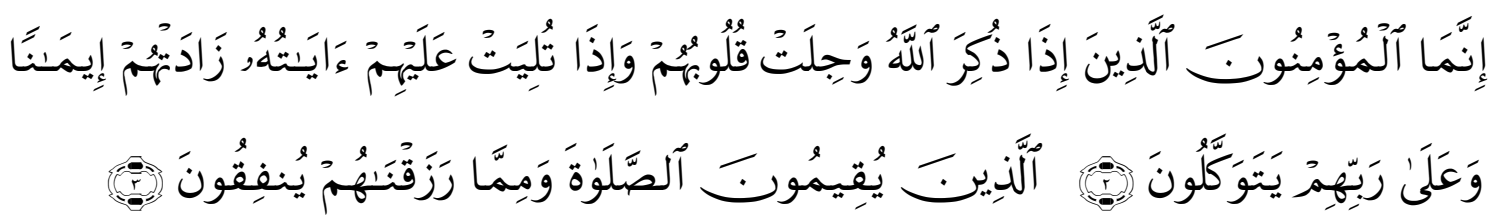

Artinya:"Sesungguhnya orang-orang yang beriman adalah mereka yang apabila disebut nama Allah gemetar hatinya, dan apabila dibacakan ayat-ayatNya kepada mereka, bertambah (kuat) imannya dan hanya kepada Tuhan mereka bertawakal. (Yaitu) orang-orang yang melaksanakan shalat dan yang menginfakkan sebagian dari rezeki yang Kami berikan kepadanya", (Q.S. alAnfāl [8] : 2-3).

Mustafa Al-Maraghi dalam menjelaskan ayat di atas membagi lima sifat seorang mukmin yang ikhlas, yakni: apabila disebut nama Allah, seorang mukmin akan mengingat kebesaran, janji dan ancamanNya; apabila dibacakan Alquran maka bertambahlah iman dan menuju kesempurnaan iman; senantiasa menyerahkan segala urusan kepada Allah (tawakkal); menjalankan salat; dan menafkahkan rezekinya karena Allah semata. ${ }^{15}$

Dalam Alquran disebutkan banyak sekali ciri-ciri orang beriman. Diantara ciriciri orang beriman adalah: pertama, orang beriman akan senantiasa menjaga salatnya. Kedua, yang menjadi ciri orang beriman adalah mereka yang berinfak dan menunaikan zakat. Selain kedua ciri tersebut, masih terdapat banyak ciri lainnya.

Berkaitan dengan Alquran yang mampu menggetarkan, dalam sebuah riwayat disebutkan bahwa Umar ibn Khattâb bersedia masuk Islam setelah membaca QS. Thâhâ: 1-6. Gemetar jiwa dan raganya. Ia pun segera menemui nabi Muhammad untuk menyatakan syahadatnya - bersaksi masuk Islam. Riwayat di atas menyiratkan pesan bahwa, orang "sekeras" Umar dapat luluh hatinya karena bacaan Alquran. ${ }^{16}$ Selain Umar, Walid ibn Mughirah juga mengalami hal serupa. Dalam sebuah riwayat, Ibn Abbâs menceritakan suatu ketika Walid mendatangi nabi, lalu nabi membacakan Alquran, maka luluh hati Walid. ${ }^{17} \mathrm{Hal}$ ini dapat diartikan bahwa siapapun yang mendengar atau pun membaca Alquran maka mendapat ketenangan hati serta bertambah imannya.

Beberapa ayat di atas menegaskan kepada setiap muslim untuk menjadikan Alquran sebagai landasan kepercayaan dalam beragama. Kepercayaan terhadap kitab suci (Alquran) merupakan salah satu aspek atau dimensi religiusitas. Diantara aspek religiusitas lainnya, seperti diterangkan Yasemin El-Menouar adalah keyakinan kepada

${ }^{15}$ Ahmad Mustafa al-Maraghi, Tafsîr al-Maraghî, (Mesir: Maktabah Musthafa, 1946), vol. 9, h. 164.

${ }^{16}$ Sayid Qutub, Taswîr al-Fannî, (Kairo: Dâr al-Syuruq, 1967), h. 12. Lihat pula: M. Quraish Shihab, Mukjizat Alquran, ditinjau dari Aspek Kebahasaan, Isyarat Ilmiah dan Pemberitaan Ghaib, (Bandung, Mizan, 1999), h. 232

${ }^{17}$ Manna al-Khallil al-Qattân, Mabâhis fî̀ Ulûm al-Qur’ân, (Kairo: Maktabah Wahbah, tt), h. 259. 
Tuhan, ritual keagamaan, praktik keagamaan (frekuensi doa), pengalaman keagamaan dan pengetahuan keagamaan. ${ }^{18}$

Sebagai salah satu mukjizat Nabi Muhammad, Alquran memiliki nilai-nilai kemukjizatan yang tidak tertandingi. Dalam beberapa literatur ulûm Alquran, disebutkan bahwa kemukjizatan Alquran (i'jâz Alquran) meliputi i'jâz ghaibî (kemukjizatan berita-berita ghaib), i'jâzlughawi (kemukjizatan segi bahasa), i'jâz 'adadi (kemukjizatan jumlah huruf), i'jâz tasyrî’i (kemukjizatan segi hukum), i'jâzilmî (kemukjizatan dari segi keilmuan). Meski secara leksikal mukjizat berarti melemahkan, tetapi ditinjau dari sisi agama ia bukan saja melemahkan atau menunjukkan ketidakmampuan yang ditantang. Mukjizat dalam hal ini Alquran ditunjukkan kepada hambaNya untuk membuktikan kebenaran ajaran Allah. ${ }^{19}$

Dalam sejarah keilmuan Alquran, tercatat ratusan bahkan ribuan karya ulama yang secara khusus membahas kemukjizatan Alquran. Para ilmuwan menuliskan karya bertemakan kemukjizatan Alquran dari sisi sains; para ahli bahasa menulis karya kemukjizatan bahasa dalam Alquran; para fuqahâ menulis sisi kemukjizatan al-Tasyrî’ Alquran, hingga seterusnya. Kandungan Alquran dapat digali dari bermacam aspek. Meski demikian, Alquran bukanlah kitab bahasa, sejarah, maupun sains. Tetapi Alquran adalah kitab petunjuk. ${ }^{20}$

Selain beberapa aspek kemukjizatan di atas, Alquran diyakini berpengaruh terhadap jiwa manusia. Oleh sebab itu Alquran diyakini mengandung kemukjizatan psikologis. Penelitian untuk mengetahui dampak psikologis kemukjizatan Alquran memang pernah dilakukan. Menurut Muhammad Kamil dalam "al-I'jâz al-Ilmî fí alQur'ân” sebagaimana dikutip Yusuf Hajaj Ahmaddan juga Quraish Shihab, telah melakukan ekperimen mengukur ketegangan saraf seseorang melalui sistem komputer saat diperdengarkan bacaan Alquran. Percobaan tersebut melibatkan orang Muslim yang pandai berbahasa Arab dan non Muslim. Mereka mendengarkan bacaan-bacaan ayat Alquran. Hasilnya, 97 persen menunjukkan adanya pengaruh ketenangan pada saraf mereka. ${ }^{21}$

Hasil penelitian tersebut setidaknya membuktikan kebenaran atas ayat Alquran yang penulis kemukakan di atas bahwa membaca dan mendengar Alquran dapat memberi rasa ketenangan jiwa. Ketenangan yang timbul setelah membaca Alquran

\footnotetext{
${ }^{18}$ Yasemin El-Menouar, "The Five Dimensions of Muslim Religiosity: Result of an Empirical Study”, dalam jurnal Methods, Data, Analyses, Vol. 8 (1), 2014, h. 53-78.

${ }^{19}$ M. Quraish Shihab, Mukjizat Alquran,h. 33

${ }^{20}$ Meski demikian, ada pula beberapa pandangan ulama yang menolak kemukjizatan Alquran. AlQattân mencatat diantara mereka adalah, Abû Ishâq Ibrahim al-Nadzam dan Murthadha. Abû Ishâq Ibrahim al-Nadzam dari kalangan Mu'tazilah yang menganggap bahwa kemukjizatan Alquran itu bukan muncul dari dalam Alquran melainkan adanya faktor eksternal. Adanya proteksi Allah terhadap Alquran sehingga siapapun yang hendak menandingi, dipalingkan. Sedangkan Murthadhaberpendapat bahwa kemampuan dan pengetahuan bahasa manusia telah dicabut oleh Allah sehingga mereka tak akan mampu membuat hal yang serupa dengan Alquran. Mereka yang berpandangan demikian disebut paham Sharfah.Manna al-Khallil al-Qattân, Mabâhis fî Ulûm al-Qur'ân, (Kairo: Maktabah Wahbah, tt), h. 253.

${ }^{21}$ Yusuf Hajaj Ahmad, Mausu'ah al-I'jâz al-Ilmî fî al-Qur'ân al-Karîm wa Sunnah al-Muthahhir, h. 598. Lihat pula: M. Quraish Shihab, Mukjizat Alquran, h. 236
} 
itulah yang disebut "kemukjizatan psikologis". Alquran memberi pengaruh secara langsung bagi jiwa pembacanya baik orang yang sudah beriman (memeluk Islam) dan mereka yang yang non muslim sekalipun.Ketika seorang muslim mencapai ketenangan, maka akan berimplikasi pada peningkatan iman (seperti semakin rajin salat dan berinfak). Namun demikian, kondisi keimanan seseorang sangat fluktuatif, terkadang meningkat dan menurun.

Dalam penelitian ini, penulis melakukan survei terhadap 150 jamaah majelis taklim di tiga majelis taklim di Kecamatan Bogor Selatan Kota Bogor untuk melihat apakah para jamaah juga merasakan adanya kemukjizatan psikologis setelah membaca Alquran.

\section{Kemukjizatan Psikologis Alquran Terhadap Jamaah Majelis Taklim}

Penelitian studi kasus ini dilakukan terhadap 150 jamaah di sebanyak tiga majelis taklim di Kecamatan Bogor Selatan Kota Bogor, yaitu Majelis Taklim Al-Barokah, At-Taqwa, dan Darul Huda Al-Hasanah. Menurut Badriah, salah seorang petugas Penyuluh Agama Honorer (PAH), data majelis taklim yang tercatat di KUA Kecamatan Bogor Selatan hingga bulan Mei 2015 sebanyak 231 majelis taklim. Dari jumlah majelis taklim tersebut, hanya 23 majelis taklim wilayah Kecamatan Bogor Selatan yang sudah terdaftar di Kemenag (kantor Kemenag Kota Bogor). Umumnya, majelis taklim di Bogor Selatan memiliki jumlah jamaah antara 30 hingga 50 jamaah. Tetapi menurut Badriah, ada pula majelis taklim yang memiliki jamaah hingga 80 bahkan 90 jamaah. ${ }^{2}$ Pemilihan majelis taklim tersebut di atas adalah rekomendasi dari Kantor Urusan Agama (KUA) dengan mempertimbangkan tingkat keaktifan kegiatan pengajian.

\section{Majelis Taklim Al-Barokah}

Majelis taklim Al-Barokah berdiri pada tahun 1999. Majelis taklim tersebut terletak di Komplek Perumahan ABRI Sukasari RT 02 RW 05 Kelurahan Lawanggintung. Kegiatan pengajian jamaah majelis taklim dilakukan di masjid alBarokah dan juga rumah ketua majelis taklim. Majelis taklim Al-Barokah telah terdaftar di Kantor Kementerian Agama Kota Bogor dengan nomor perizinan 235/TPQ/TPA/MT/13/2008. Ketua majelis dan sekaligus ustadz majelis taklim AlBarokah adalah Bapak Ade Mulyana. ${ }^{23}$

Berdirinya majelis taklim Al-Barokah dilatarbelakangi oleh kebutuhan masyarakat sekitar akan pengetahuan agama. Sebelum tahun 1999, di lingkungan masjid Al-Barokah belum ada satu kegiatan pengajian, baik pengajian anak-anak ataupun ibu-ibu. Hal ini yang kemudian mendorong Ade Mulyana untuk mendirikan majelis taklim. Keberadaan majelis taklim Al-Barokah mendapat perhatian khusus dari

\footnotetext{
${ }^{22}$ Wawancara pribadi dengan Badriah (Penyuluh Agama Honorer), Bogor Selatan, Kota Bogor, 29 Mei 2015

${ }^{23}$ Wawancara pribadi dengan Ade Mulyana (Ketua Majelis Taklim al-Barokah), Bogor Selatan, Kota Bogor, 29 Mei 2015
} 
pemerintah, mulai dari tingkat RT hingga Pemerintah Kota Bogor. Ade merasa mendapat perhatian lebih dari aparat pemerintah. Ia juga menyampaikan bahwa majelis taklimnya pernah mendapat bantuan dana dari pemerintah. ${ }^{24}$

Setelah beberapa tahun berdiri, majelis taklim mendapat respon positif dari masyarakat lingkungan sekitar. Menurut Ade, masyarakat semakin antusias dengan adanya pengajian di masjid Al-Barokah. Antusiasme masyarakat terlihat dalam beberapa kegiatan keagamaan yang dilaksanakan di lingkungan majelis taklim. Jamaah yang melaksanakan salat berjamaah pun meningkat, demikian pula dengan pengajian dan infak yang dikeluarkan masyarakat sekitar. Jumlah jamaah majelis taklim sekitar 50 hingga 100 jamaah. Pada peringatan hari besar Islam tertentu, jumlah bisa melebihi jumlah tersebut.

Berkenaan dengan cara memahami ayat Alquran yang dilakukan jamaah AlBarokah, dari 50 jamaah, sebanyak 44 jamaah menyebut cara yang dilakukan guna memahami Alquran adalah dengan mendengar penjelasan dari ustadz pengajar di majelis taklim. Selanjutnya 4 jamaah menyebut membaca Alquran terjemah dan 2 jamaah tidak menjawab.

Alquran yang dibaca, didengar dan dipahami para jamaah majelis taklim memberi pengaruh ketenangan bagi mereka. Terkait dengan hal itu, dari 50 jamaah, sebanyak 24 jamaah menyatakan sangat tenang dan 26 jamaah menyatakan tenang.

Diagram: ketenangan dan ketentraman hati setelah membaca atau mendengar bacaanbacaan ayat Alquran (tahap I)

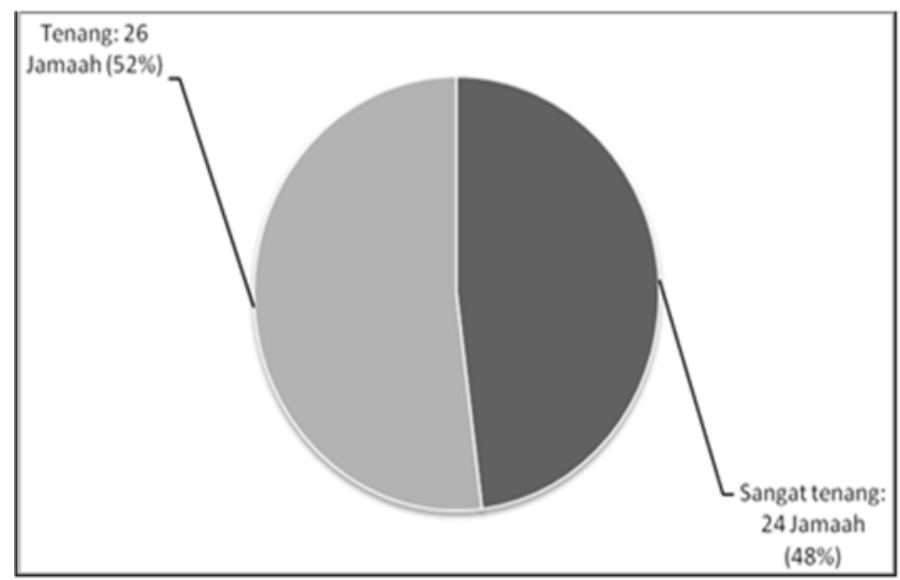

Setelah berselang lima bulan, penulis kembali membagikan angket tahap kedua terkait ketenangan setelah membaca Alquran yang dirasakan para jamaah. Data angket tahap kedua menunjukkan 37 jamaah merasa sangat tenang dan 13 jamaah merasa tenang.

${ }^{24}$ Wawancara pribadi dengan Ade Mulyana(Ketua Majelis Taklim al-Barokah), Bogor Selatan, Kota Bogor, 29 Mei 2015 
Diagram: ketenangan dan ketentraman hati setelah membaca atau mendengar bacaanbacaan ayat Alquran (tahap II)

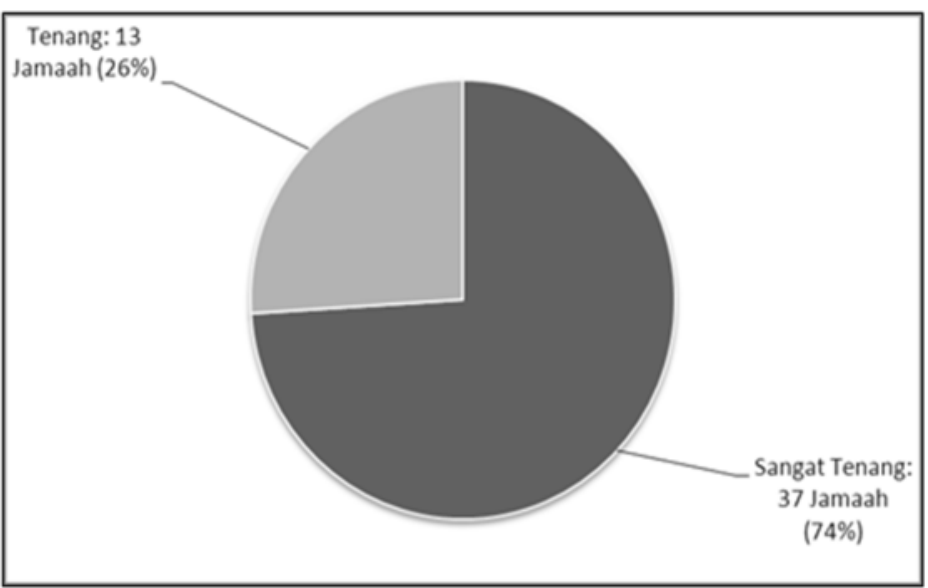

Selanjutnya penulis sajikan data terkait dengan ibadah salat dan infak yang dilakukan para jamaah majelis taklim. Dua hal ini merupakan indikator iman seseorang.Terkait pertanyaan mengenai pelaksanaan salat berjamaah, penulis akan memaparkan hasil pengisian angket tahap pertama. Para jamaah memberi jawaban yang beragam. Dari 50 jamaah, sebanyak 20 jamaah menyebut satu kali salat berjamaah dalam sehari, 2 jamaah menyebut dua kali salat berjamaah dalam sehari, 2 jamaah menyebut lima kali salat berjamaah dalam sehari. Adapun jumlah jamaah yang melaksanakan salat sendiri sebanyak 23 jamaah dan 3 jamaah sisanya tidak menjawab. Gambaran tersebut dapat dilihat pada diagram di bawah ini.

Diagram: pelaksanaan salat berjamaah dalam satu hari (tahap I)

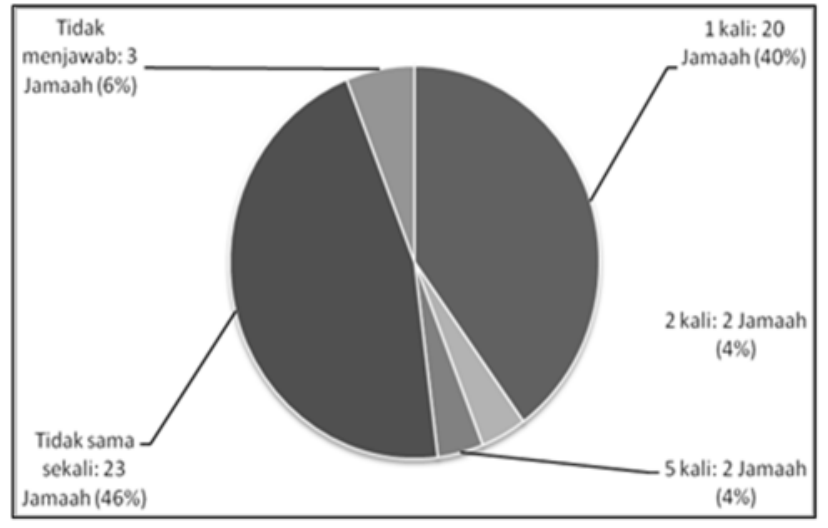

Selanjutnya pada pengisian angket tahap kedua, penulis kembali menggali data jamaah melalui angket terkait kegiatan salat berjamaah. Data angket tahap kedua menunjukkan dari 50 jamaah, 1 jamaah menyebut dua kali salat berjamaah, 2 jamaah menyebut tiga kali, 1 jamaah menyebut empat kali, dan 46 jamaah menyebut tidak sama sekali. Namun demikian, para jamaah menyebut bahwa ketidakhadiran salat berjamaah di masjid diakibatkan cuaca hujan. 
Diagram: pelaksanaan salat berjamaah dalam satu hari (tahap II)

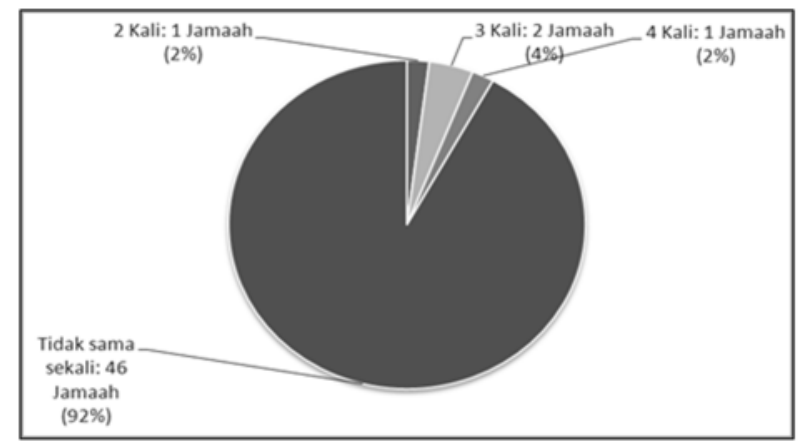

Berkenaan dengan infak yang dikeluarkan para jamaah dalam sepekan, menurut data yang penulis kumpulkan dari 50 jamaah melalui angket, sebanyak 32 jamaah menyebut sering berinfak; 11 jamaah menyebut hanya satu kali berinfak; 2 jamaah menyebut dua kali berinfak; 2 jamaah juga menyebut empat kali berinfak; 1 jamaah menyebut tiga kali berinfak dan sisanya 2 jamaah tidak menyebutkan.

Diagram: infak jamaah dalam satu minggu (tahap I)

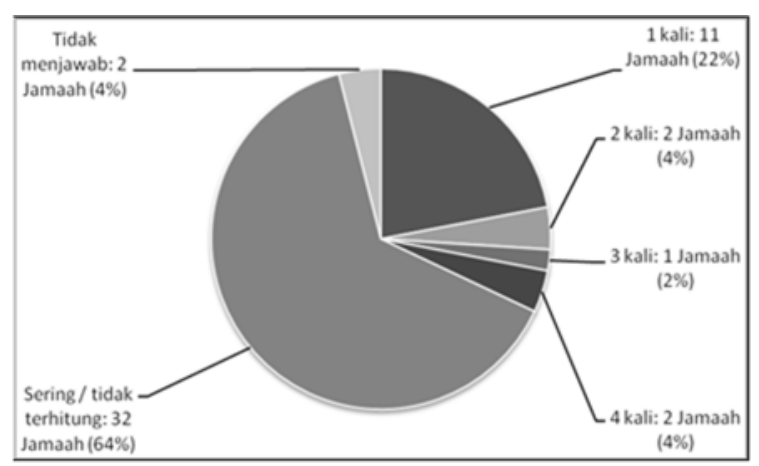

Pada tahap kedua pengisian angket terkait infak yang dilakukan jamaah dalam sepekan menunjukkan hasil sebagai berikut: 14 jamaah menjawab satu kali, 11 jamaah menjawab dua kali, 3 jamaah menjawab tiga kali, dan 21 jamaah menjawab sering/tidak terhitung.

Diagram: infak jamaah dalam satu minggu (tahap II)

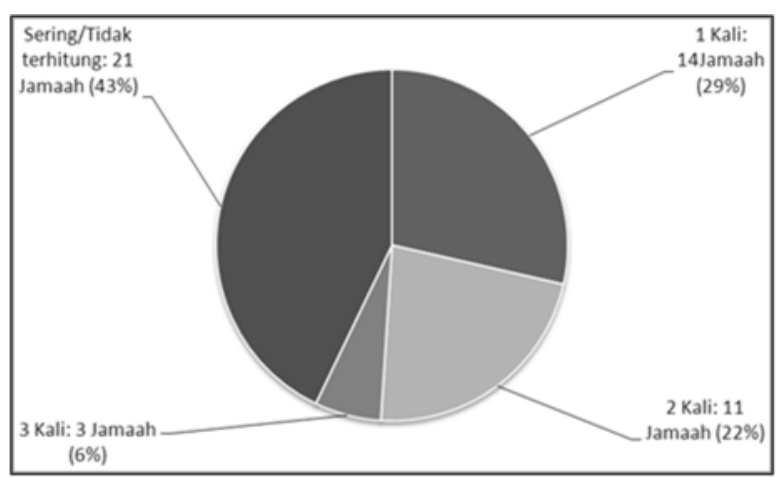




\section{Majelis Taklim At-Taqwa}

Majelis At-Taqwa termasuk majelis yang cukup tua karena didirikan pada tahun 1976 yang terletak di J1. Pahlawan Jerokuta Kidul Kelurahan Empang, Bogor Selatan. ${ }^{25}$ Majelis tersebut berada di bawah organisasi Dewan Kemakmuran Masjid At-Taqwa seksi Pengembangan Potensi Muslimah. Berdirinya majelis taklim ini diprakarsai oleh jamaah kaum ibu disekitar lingkungan masjid. Majelis taklim At-Taqwa diketuai oleh Hj. Sussy Wijaya Drie Warsono. ${ }^{26}$

Majelis At-Taqwa memiliki peran penting di tengah masyarakat lingkungan masjid. Keberadaannya menjadi pelita bagi kehidupan masyarakat. Mereka dapat menimba ilmu agama di bawah bimbingan para ustadz. Hal ini sangat sesuai dengan salah satu fungsi majelis taklim, sebagai tempat belajar agama. Menurut Sussy (ketua majelis taklim At-Taqwa), jamaah dan masyarakat sekitar majelis merespon baik keberadaan dan kegiatan majelis taklim. Pemerintah setempat, mulai dari RT hingga kelurahan juga mendukung sepenuhnya kegiatan majelis taklim. ${ }^{27}$

Pelajaran Alquran yang dipelajari di majelis taklim memberikan pengaruh yang cukup signifikan pagi para jamaah. Para jamaah majelis taklim At-Taqwa memahami ayat dengan beragam cara. Para jamaah tidak hanya mengaji Alquran di majelis saja, mereka juga mengaji Alquran di rumah. Dari pengumpulan data terhadap 50 jamaah, sebanyak 49 jamaah menyatakan bahwa mereka mengaji di rumah, dan hanya 1 jamaah yang mengaku tidak mengaji di rumah.

Berkenaan dengan cara memahami ayat Alquran, ada beberapa cara yang dilakukan oleh jamaah. Melalui pengumpulan data dari 50 jamaah yang penulis lakukan, sebanyak 41 jamaah menjawab cara yang dilakukan guna memahami Alquran adalah dengan mendengar penjelasan dari ustadz pengajar di majelis taklim; 3 jamaah menjawab mendengar penjelasan dari ustadz atau ustadzah di pengajian televisi; 2 jamaah membaca Alquran terjemah; dan 4 jamaah bertanya kepada jamaah lainnya. Dengan pemahaman yang baik dan holistik terhadap ayat-ayat Alquran, akan memberi pengaruh bagi pembacanya.

Terkait dengan pengaruh ketenangan dan ketentraman hati setelah membaca Alquran, dari 50 jamaah, sebanyak 23 jamaah menyatakan sangat tenang; 26 jamaah menyatakan tenang; dan 1 jamaah menyatakan tidak tenang.

Diagram: ketenangan dan ketentraman hati setelah membaca atau mendengar bacaanbacaan ayat Alquran (tahap I)

25 Di kelurahan Emapang juga terdapat banyak majelis taklim. Menurut Sussy di kelurahan Emapang terdapat 20 Rukun Warga (RW). Sussy meyakini bahwa disetiap RW terdapat satu majelis taklim bahkan bias lebih. Majelis taklim di kelurahan Empang tidak saja dilakukan di masjid, tetapi terkadang di musallah. Wawancara pribadi dengan Sussy Wijaya Drie Warsono, Bogor Selatan, Kota Bogor 2 Juni 2015

${ }^{26}$ Wawancara pribadi dengan Sussy Wijaya Drie Warsono (Ketua Majelis Taklim at-Takwa), Bogor Selatan, Kota Bogor 2 Juni 2015

${ }^{27}$ Wawancara pribadi dengan Sussy Wijaya Drie Warsono, (Ketua Majelis Taklim atTakwa),Bogor Selatan, Kota Bogor 2 Juni 2015 


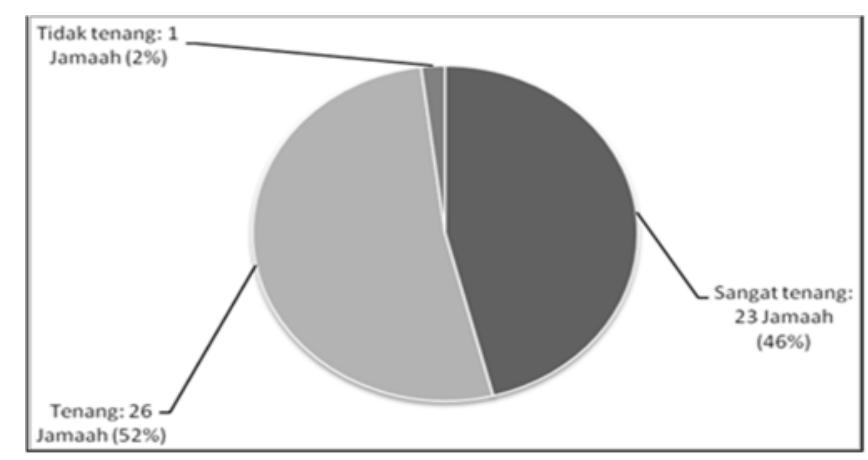

Setelah lima bulan berselang, penulis kembali membagikan angket tahap kedua untuk mendapatkan informasi terkait ketenangan setelah membaca Alquran yang dilakukan para jamaah. Data angket tahap kedua menunjukkan 39 jamaah menyebut sangat tenang, dan 11 jamaah menyebut tenang. Hasil pada tahap kedua ini berbeda dengan tahap pertama, yang salah satu dari jamaah menyebut tidak tenang.

Diagram: ketenangan dan ketentraman hati setelah membaca atau mendengar bacaanbacaan ayat Alquran (tahap II)

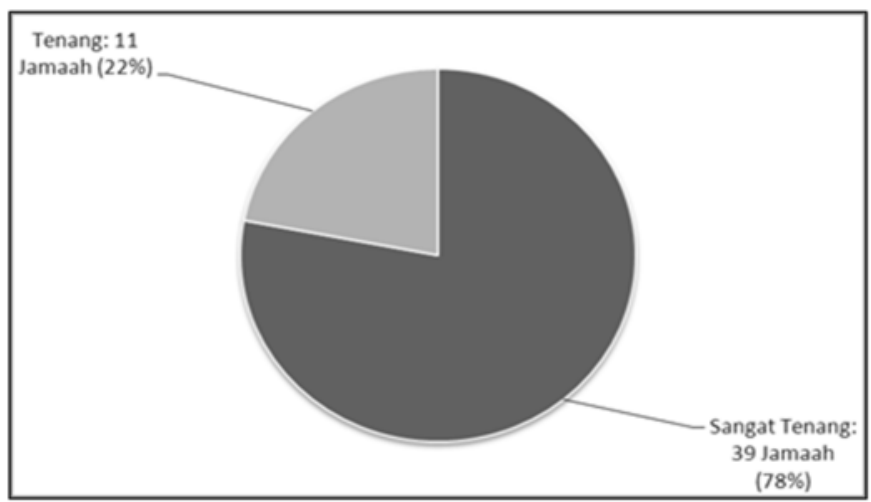

Terkait dengan pelaksanaan salat berjamaah, tidak semua jamaah menyatakan salat berjamaah salat lima waktu. Dari 50 jamaah, sebanyak 22 jamaah menyatakan hanya satu kali melakukan salat berjamaah dalam sehari; 6 jamaah melakukan dua kali salat berjamaah dalam sehari; 2 jamaah melakukan tiga kali salat berjamaah dalam sehari; dan hanya 6 jamaah yang melakukan salat berjamaah lima kali dalam sehari. Selebihnya, 13 jamaah tidak melakukan salat berjamaah dan 1 jamaah yang tidak menjawab. Gambaran tersebut dapat dilihat pada diagram di bawah ini.

Diagram: pelaksanaan salat berjamaah dalam satu hari (tahap I)

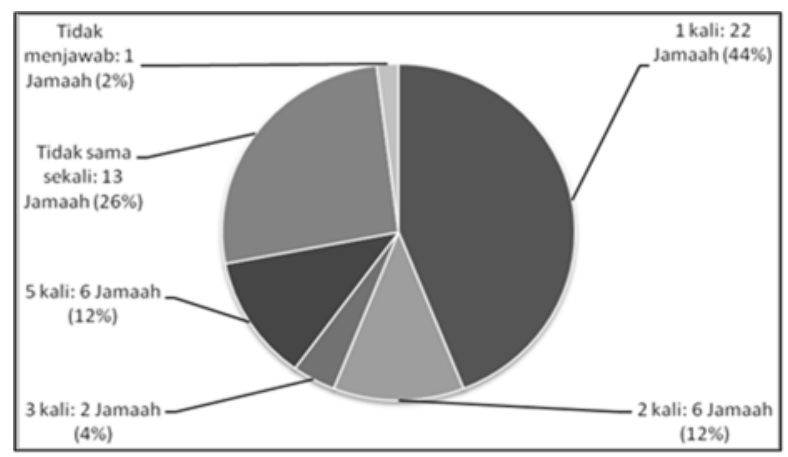


Selanjutnya pada pengisian angket tahap kedua, penulis kembali menggali data jamaah melalui angket terkait pelaksanaan kegiatan salat berjamaah. Data anget tahap kedua menunjukkan 25 jamaah menjawab satu kali salat berjamaah, 6 jamaah menjawab dua kali, 5 jamaah menjawab 3 kali, 3 jamaah menjawab 5 kali, dan 11 jamaah tidak sama sekali.

Diagram: pelaksanaan salat berjamaah dalam satu hari (tahap II)

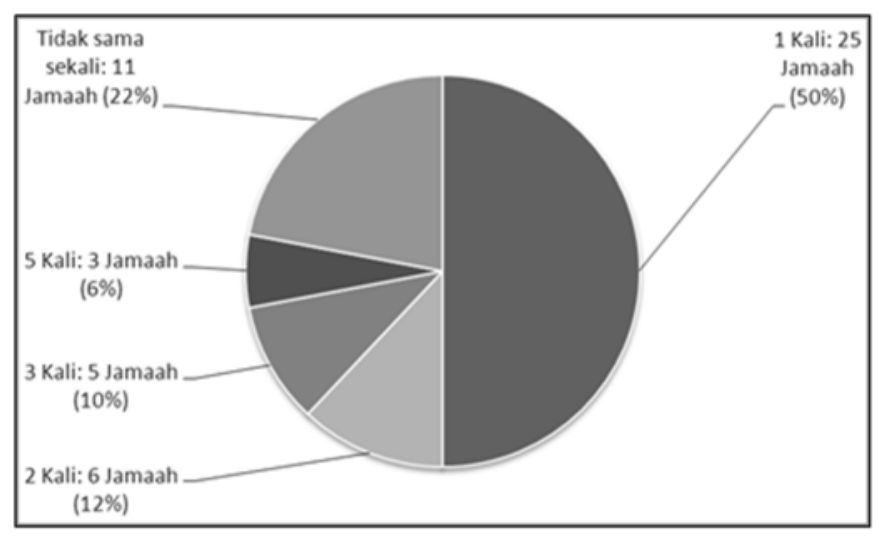

Penulis juga mengajukan pertanyaan terkait seberapa sering para jamaah berinfak dalam satu minggu. Dari pengumpulan data terhadap 50 jamaah melalui angket, sebanyak 16 jamaah menjawab satu kali berinfak dalam sepekan; 3 jamaah berinfak dua kali dalam sepekan; 2 jamaah berinfak tiga kali dalam sepekan; 2 jamaah juga berinfak empat kali dalam sepekan; 26 jamaah menjawab sering berinfak dalam sepekan dan 1 jamaah tidak menjawab.

Diagram: infak jamaah dalam satu minggu (tahap I)

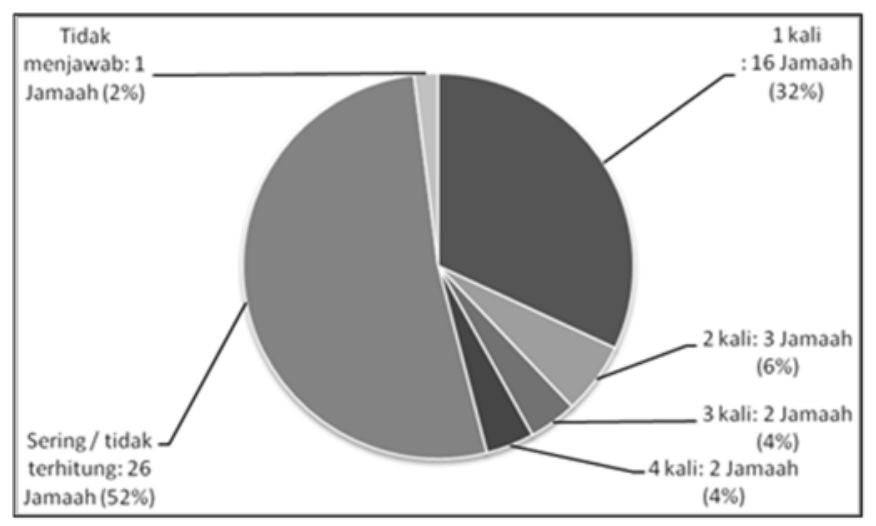

Pada tahap kedua pengisian angket terkait infak yang dilakukan jamaah menunjukkan hasil sebagai berikut: 15 jamaah menjawab satu kali, 4 jamaah menjawab dua kali, 5 jamaah menjawab tiga kali, 8 jamaah menjawab 4 kali, dan 18 jamaah menjawab sering/tidak terhitung. 
Diagram: infak jamaah dalam satu minggu (tahap II)

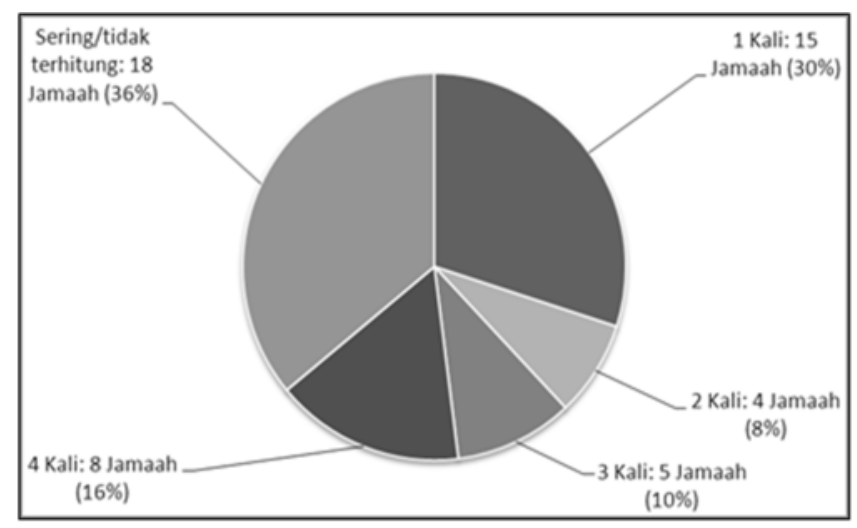

Beberapa jamaah menyampaikan bahwa mereka lebih sering melakukan infak pada saat pengajian, melalui kotak amal yang terdapat di masjid. Selain itu, ada pula jamaah yang menyebutkan bahwa terkadang ia berinfak di jalan dan di pasar. Ia memberikan hartanya kepada orang yang tidak mampu dengan niat infak.

\section{Jamaah Majelis Taklim Darul Huda Al-Hasanah}

Majelis taklim Darul Huda Al-Hasanah (selanjutnya disingkat DHA) terletak di Kampung Indah Sari RT 03 RW 01, Kelurahan Harjasari, Kecamatan Bogor SelatanKota Bogor. ${ }^{28}$ Majelis ini berdiri pada tahun 1994, tepatnya bulan November. Majelis taklim DHA dipimpin oleh $\mathrm{H}$. Oha. Ia sekaligus menjadi ustadz atau pengajar. Berikut susunan organisasi majelis taklim DHA.

Oha mempunyai alasan kuat mendirikan majelis taklim DHA. Salah satu alasan terkuat adalah bahwa ia ingin mamanfaatkan ilmu yang ia dapat selama di pesantren dahulu. Selain itu, ia ingin merawat dakwah nabi Muhammad, mengajarkan dan menjaga ajaran Islam. Oha juga melihat kebutuhan masyarakat akan pembelajaran ilmu agama. Itulah sebabnya ia mendirikan majelis taklim. Setelah mendirikan majelis taklim ini, ia bercita-cita untuk mendirikan pesantren. Oleh karenannya, majelis taklim tersebut sudah terdaftar di Kantor Kementerian Agama Kota Bogor dengan status pesantren. $^{29}$

Menurut hasil pengumpulan data yang penulis lalukan terhadap 50 jamaah, semuanya menyebutkan bahwa mereka mengaji Alquran di rumah. Berkenaan dengan cara memahami ayat Alquran, melalui pengumpulan data dari 50 jamaah yang penulis lakukan, sebanyak 45 jamaah menjawab cara yang dilakukan guna memahami Alquran adalah dengan mendengar penjelasan dari ustadz pengajar di majelis taklim; 2 jamaah menjawab mendengar penjelasan dari ustadz atau ustadzah di pengajian televisi; dan 3 jamaah membaca Alquran terjemah.

\footnotetext{
${ }^{28}$ Menurut keterangan yang penulis dapat, di Kelurahan Harjasari terdapat sekitar 10 bahkan lebih majelis taklim. Wawancara pribadi dengan Oha, Bogor Selatan(Ketua Majelis Taklim Darul Huda alHasanah), Kota Bogor 7 Juni 2015

${ }^{29}$ Wawancara pribadi dengan Oha, (Ketua Majelis Taklim Darul Huda al-Hasanah), Bogor Selatan, Kota Bogor 7 Juni 2015
} 
Membaca dan mendengarkan Alquran yang dilakukan para jamaah memberi pengaruh tersendiri bagi mereka, terutama ketenangan dan ketentraman jiwa dan hati. Menurut data yang penulis kumpulkan dari 50 jamaah, sebanyak 35 jamaah menyebutkan adanya rasa tenang dan ketentraman hati setelah membaca atau ketika mendengar bacaan Alquran. Dan, 15 jamaah menyebutkan perasaan sangat tenang setelah membaca dan mendengar bacaan Alquran.

Diagram: ketenangan dan ketentraman hati setelah membaca atau mendengar bacaanbacaan ayat Alquran (tahap I)

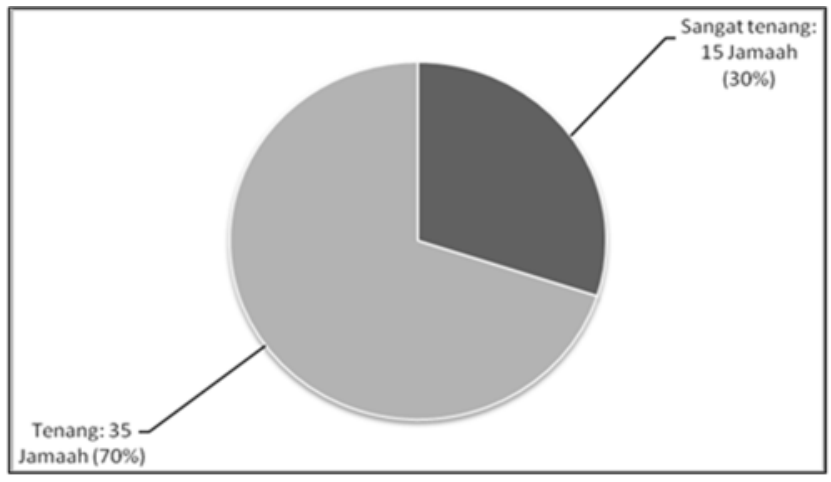

Setelah lima bulan berselang, penulis kembali membagikan angket tahap kedua terkait keadaan ketenangan setelah membaca Alquran yang dilakukan para jamaah. Data angket tahap kedua menunjukkan 45 jamaah merasa sangat tenang, dan 5 jamaah merasa tenang.

Diagram: ketenangan dan ketentraman hati setelah membaca atau mendengar bacaanbacaan ayat Alquran (tahap II)

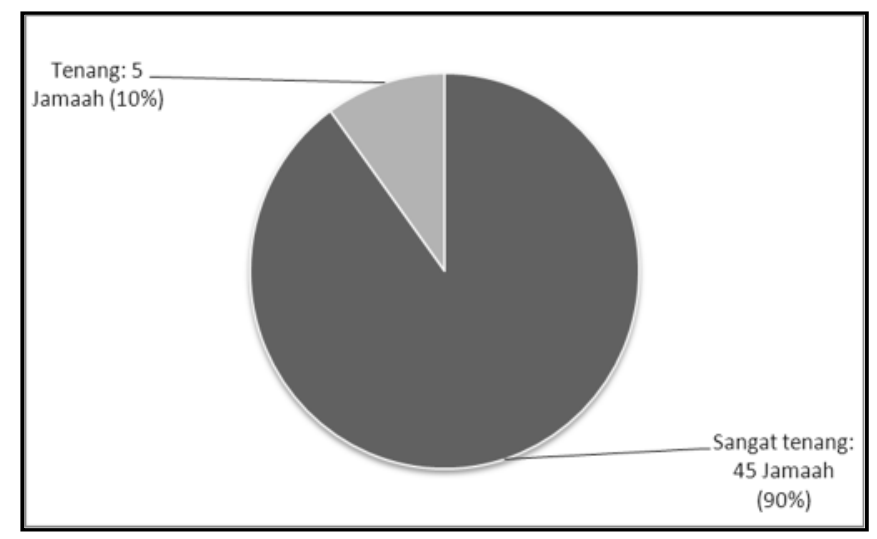

Berkenaan dengan salat berjamaah yang dilakukan dalam sehari, dari 50 jamaah sebanyak 25 jamaah menyebutkan bahwa mereka melaksanakan salat berjamaah lima kali (waktu) dalam sehari. Selanjutnya 10 jamaah menyebutkan satu kali salat berjamaah, 5 jamaah menyebutkan dua kali, 3 jamaah menyebutkan empat kali, 2 jamaah menyebutkan 3 kali dan 5 jamaah menyebut tidak berjamaah sama sekali. 
Diagram: pelaksanaan salat berjamaah dalam satu hari (tahap I)

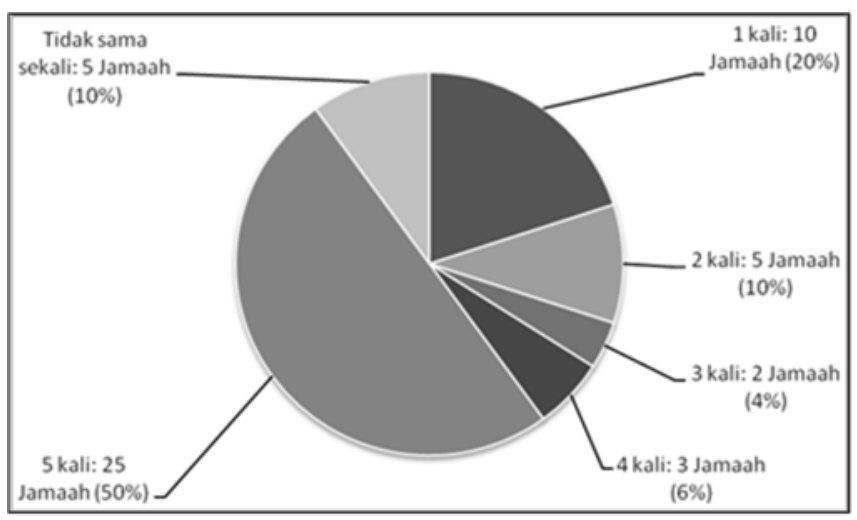

Selanjutnya pada pengisian angket tahap kedua, penulis kembali menggali data jamaah melalui angket terkait pelaksanaan kegiatan salat berjamaah. Data anget tahap kedua menunjukkan 10 jamaah menyebut dua kali salat berjamaah, 20 jamaah menjawab tiga kali, 3 jamaah menjawab empat kali, dan 17 jamaah menjawab 5 kali.

Diagram: pelaksanaan salat berjamaah dalam satu hari (tahap II)

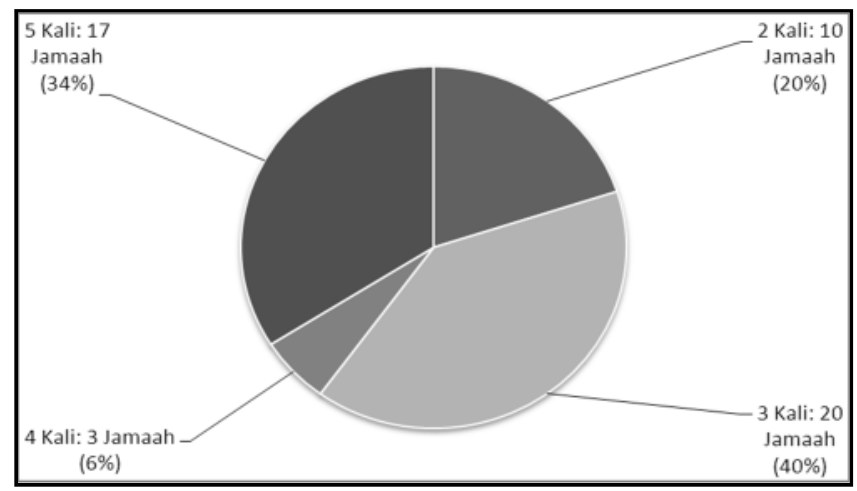

Sedangkan berkenaan dengan infak yang dilakukan dalam sepekan oleh para jamaah, umumnya mereka gemar berinfak hingga tidak ingat berapa kali berinfak. Dari angket yang diisi oleh 50 jamaah, sebanyak 32 jamaah menjawab sering berinfak, 5 jamaah menjawab empat kali, 4 jamaah menjawab tiga kali, 3 jamaah menjawab satu kali, 2 jamaah menjawab dua kali dan 4 jamaah tidak menjawab.

Diagram: infak jamaah dalam satu minggu (tahap I)

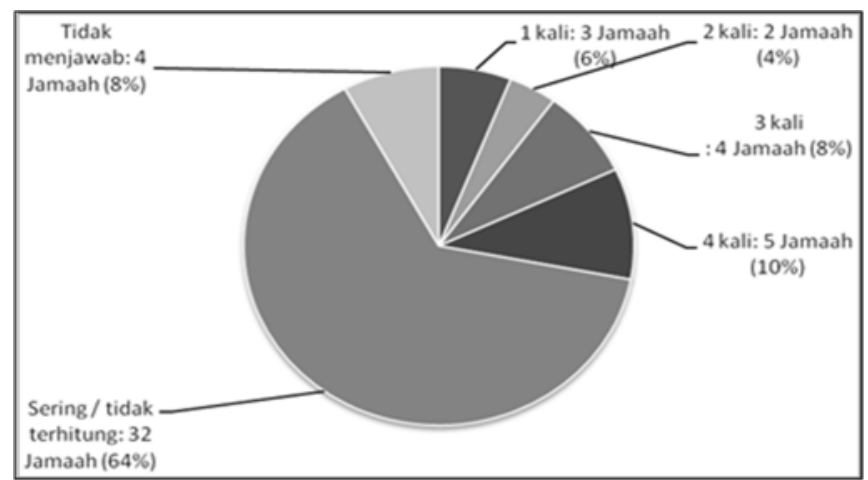


Pada tahap kedua pengisian angket terkait infak yang dilakukan jamaah dalam sepekan menunjukkan hasil sebagai berikut: 4 jamaah menjawab satu kali, 18 jamaah menjawab dua kali, 19 jamaah menjawab tiga kali, 7 jamaah menjawab empat kali, dan 2 jamaah menjawab sering/tak terhitung.

Diagram: infak jamaah dalam satu minggu (tahap II)

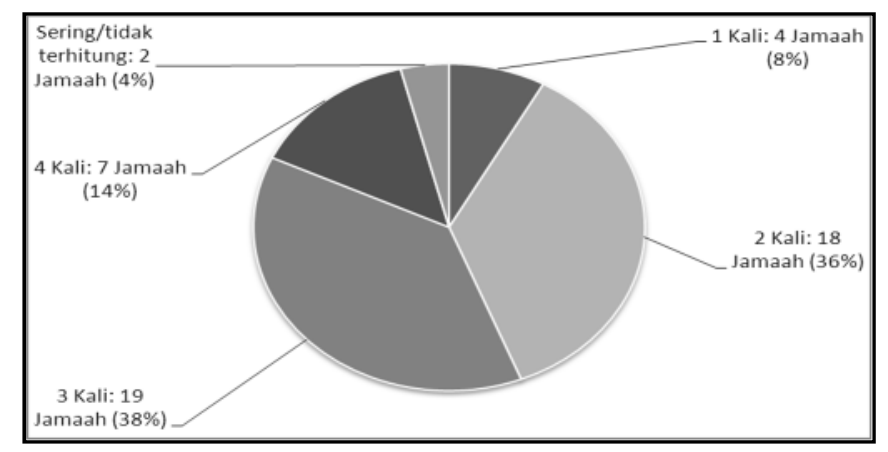

Berdasarkan uraian hasil wawancara di atas, penulis hanya membandingkan tiga hal penting, yakni: Ketenangan dan ketentraman setelah membaca dan mendengar Alquran, jumlah jamaah yang melaksanakan salat lima waktu dalam sehari, dan jumlah jamaah yang sering berinfak.

Jika dilihat dari beberapa diagram di atas yang menunjukkan kemukjizatan psikologis pada majelis taklim, penulis menemukan hasil bahwa hampir semua jamaah mendapat ketenangan dan ketentraman setelah membaca dan mendengar Alquran. Meski demikian jumlah mereka dari tiga majelis taklim beragam. Terkait jumlah jamaah majelis taklim Al-Barokah yang menyebutkan ketenangan setelah mambaca dan mendengar Alquran pada tahap pertama menunjukkan sebanyak 50 jamaah menyebut merasa tenang dengan rincian: 24 (48\%) jamaah sangat tenang dan 26 (52\%) jamaah menyebut tenang. Sedangkan pada tahap kedua, sebanyak 37 (74\%) jamaah menyebut sangat tenang dan $13(26 \%)$ jamaah menjawab tenang.

Pada majelis taklim At-Taqwa, pada tahap pertama menunjukkan sebanyak 49 jamaah menyebut merasa tenang dengan rincian: 23 (46\%)jamaah menyebut sangat tenang dan 26 (52\%)jamaah menyebut tenang. Dan, hanya ada 1 jamaah yang menyebut tidak tenang. Pada tahap kedua, sebanyak 39 (79\%) menyebut sangat tenang dan $11(22 \%)$ jamaah menyebut tenang.

Sedangkan pada majelis taklim DHA, pada tahap pertama menunjukkan 50 jamaah menyebut tenang dengan rincian: 15 (30\%) jamaah menyebut sangat tenang dan 35 (70\%) jamaah menyebut tenang. Dan, pada tahap kedua menunjukkan sebanyak 45 (90\%) jamaah menyebut sangat tenang dan 5 (10\%) jamaah menyebut tenang.

Dalam hal pelaksanaan salat lima waktu berjamaah dalam sehari, untuk jamaah majelis taklim Al-Barokah hanya sebanyak 2 (4\%) jamaah, majelis taklim At-Taqwa sebanyak 6 (12\%) jamaah dan majelis taklim DHA sebanyak 25 (50\%) jamaah. Terkait dengan infak yang sering dikeluarkan jamaah dalam sepekan, untuk majelis taklim Al- 
Barokah sebanyak 32 (64\%) jamaah, majelis taklim At-Taqwa sebanyak 26 (52\%) jamaah dan majelis taklim DHA sebanyak 32 (64\%) jamaah. Selanjutnya dapat dilihat pada tabel di bawah ini:

Tabel: Analisa perbandingan tiga majelis taklim (pada tahap pertama) terkait ketengangan setelah membaca dan mendengar Alquran; jumlah jamaah yang salat lima waktu sehari dan jumlah jamaah yang sering berinfak.

\begin{tabular}{|l|c|c|c|c|}
\hline \multirow{2}{*}{$\begin{array}{c}\text { Majelis } \\
\text { Taklim }\end{array}$} & \multicolumn{2}{|c|}{$\begin{array}{c}\text { Ketenangan dan ketentraman setelah } \\
\text { membaca dan mendengar Alquran }\end{array}$} & $\begin{array}{c}\text { Jamaah yang } \\
\text { melaksana-kan salat } \\
5 \text { waktu } \\
\text { berjamaah }\end{array}$ & $\begin{array}{c}\text { Jamaah yang } \\
\text { sering berinfak }\end{array}$ \\
\cline { 2 - 5 } & Sangat tenang & Tenang & $2(4 \%)$ jamaah & $32(64 \%)$ jamaah \\
\hline Al-Barokah & $\begin{array}{c}24(48 \%) \\
\text { jamaah }\end{array}$ & $26(52 \%)$ jamaah & $26(12 \%)$ jamaah & $26(52 \%)$ jamaah \\
\hline At-Taqwa & $23(46 \%)$ jamaah & $26(52 \%)$ jamaah & $25(50 \%)$ jamaah & $32(64 \%)$ jamaah \\
\hline $\begin{array}{l}\text { Darul Huda } \\
\text { Al-Hasanah }\end{array}$ & $\begin{array}{c}15(30 \%) \\
\text { jamaah }\end{array}$ & $35(70 \%)$ jamaah & 2 & \\
\hline
\end{tabular}

Tabel: Analisa perbandingan tiga majelis taklim (pada tahap kedua) terkait ketengangan setelah membaca dan mendengar Alquran; jumlah jamaah yang salat lima waktu sehari dan jumlah jamaah yang sering berinfak.

\begin{tabular}{|c|c|c|c|c|}
\hline \multirow{2}{*}{$\begin{array}{c}\text { Majelis } \\
\text { Taklim }\end{array}$} & \multicolumn{2}{|c|}{$\begin{array}{c}\text { Ketenangan dan ketentraman setelah } \\
\text { membaca dan mendengar Alquran }\end{array}$} & $\begin{array}{c}\text { Jamaah yang } \\
\text { melaksana-kan salat } \\
5 \text { waktu } \\
\text { berjamaah }\end{array}$ & $\begin{array}{c}\text { Jamaah yang } \\
\text { sering berinfak }\end{array}$ \\
\cline { 2 - 5 } & Sangat tenang & Tenang & & \\
\hline Al-Barokah & $37(74 \%)$ jamaah & $13(26 \%)$ jamaah & $0(0 \%)$ jamaah & $21(42 \%)$ jamaah \\
\hline At-Taqwa & $39(79 \%)$ jamaah & $11(22 \%)$ jamaah & $3(6 \%)$ jamaah & $18(36 \%)$ jamaah \\
\hline $\begin{array}{l}\text { Darul Huda } \\
\text { Al-Hasanah }\end{array}$ & $45(90 \%)$ jamaah & $5(10 \%)$ jamaah & $17(34 \%)$ jamaah & $2(4 \%)$ jamaah \\
\hline
\end{tabular}

Jika melihat hasil survei tahap pertama dan kedua, terdapat perbedaan yang cukup signifikan. Pertama, pada tahap pertama survei, jamaah yang merasakan ketenangan lebih sedikit dari pada pada survei tahap kedua. Kedua, pada tahap kedua survei, indikator meningkatnya iman (rajin salat berjamaah dan berinfak) lebih kecil dibanding hasil survei tahap pertama meskipun ketenangan (rasa sangat tenang) yang dirasakan jamaah meningkat. Ini menunjukkan bahwa ketenangan yang dirasakan jamaah yang membaca Alquran tidak selalu meningkatkan intensitas salat berjamaah dan berinfak. Hal ini dapat dimaklumi karena kedua indikator iman tersebut (salat dan infak) bersifat fluktuatif.

\section{Penutup}

Berdasarkan hasil dan analisis penelitian ini, penulis menyimpulkan bahwa mayoritas para jamaah dapat memahami kandungan Alquran melalui penjelasan pengajar di majelis taklim. Pengajian yang mereka ikuti merupakan media untuk memahami ajaran agamaterutama Alquran. Bagi para jamaah, Alquran memiliki posisi penting dalam kehidupan mereka. Membaca dan mendengar Alquran yang dilakukan memberi pengaruh bagi ketenangan jiwa, adanya kemukjizatan psikologis. Dari analisis 
data yang penulis lakukan survei tahap pertama, hanya terdapat 1 dari 150 responden jamaah yang menyatakan tidak tenang setelah membaca Alquran. Sedangkan pada survei tahap kedua, jamaah yang menyatakan sangat tenang lebih banyak dari pada sekedar tenang.

Membaca dan mendengar Alquran berdampak pada peningkatan iman dan perilaku positif jamaah majelis taklim. Terkait hal ini, penulis menggunakan dua indikator peningkatan iman yaitu: salat dan infak. Namun demikian, hasil penelitian ini menunjukkan bahwa ketenangan setelah membaca Alquran tidak selalu meningkatkan intensitas salat berjamaah dan berinfak para jamaah. Temuan ini sejalan dengan konsep bahwa keimanan tidak bisa berjalan konstan/konsisten karena dapat bertambah dan berkurang.

Penulis juga mendapat keterangan dari para ustadz pengajar di majelis taklim bahwa keberadaan dan kegiatan pengajian majelis taklim memberi pengaruh bagi kehidupan jamaahnya. Sebagai contoh pada majelis taklim At-Takwa terdapat jamaah yang sebelum mengikuti pengajian mempunyai sifat pemarah. Tetapi setelah aktif dalam pengajian, perlahan jamaah tersebut menjadi pribadi yang penyabar. 


\section{DAFTAR PUSTAKA}

Abadi. Abî Thâhir ibn Ya'qûb al-Fairuzi, Tanwîr al-Mi'bâs min Tafsîr Ibn Abbâs, Bairut: Dâr al-Fikr, 2001.

Ahmad. Yusuf Hajaj, Mausu'ah al-I'jâz al-Ilmî fî al-Qur'ân al-Karîm wa Sunnah alMuthahhir, Damaskus: Maktabah Ibn Hajr, 2003.

Departemen Agama RI, Alquran dan Terjemahnya, Tahun 2006.

al-Ghazali. Muhammad, Kaifa Nata'amal ma'a Alquran, Kairo: Nahdetmisr, 2005

Hasan. Muhammad Tholchah, Dinamika Kehidupan Religius, Jakarta: Listafariska Putera, 2000.

Mack. Natasha. dkk, Qualitative Reserch Methods: A Data Celloctor Field Guide, California: Family Health International, 2005.

al-Maraghi. Ahmad Mustafa, Tafsîr al-Maraghî, Mesir: Maktabah Musthafa, 1946.

Saleh. Abdul Rahman, Psikologi: Suatu Pengantar dalam Perspektif Islam, Jakarta: Kencana Prenada Media Grup, 2008.

Shihab. M. Quraish, Tafsir Al-Misbah: Pesan, Kesan dan Keserasian Alquran, Jakarta: Lentera Hati, 2002.

. M. Quraish, Mukjizat Alquran, ditinjau dari Aspek Kebahasaan, Isyarat Ilmiah dan Pemberitaan Ghaib, Bandung, Mizan, 1999.

al-Sijistani. Abî Dâud Sulaimân ibn al-Asy'ats, Sunan Abî Dâud, Beirut: Dâr al-Kitab al-'Arabi, tt.

Syakur. Abd, "Metode Ketenangan Jiwa (Suatu Perbandingan Antara al-Ghazali dan Sigmund Freud)", dalam Jurnal Islamica, Vol. 1, No. 2, Maret 2017.

Suryanto. Bagong -Sutinah (ed), Metode Penelitian Sosial: Berbagai Alternatif Pendekatan, Jakarta: Kencana Prenada Media Group, 2005.

al-Qattân. Manna al-Khallil, Mabâhis fî Ulûm al-Qur'ân, Kairo: Maktabah Wahbah, tt.

Qutub. Sayid, Taswîr al-Fannî, Kairo: Dâr al-Syuruq, 1967.

Yasemin El-Menouar, "The Five Dimensions of Muslim Religiosity: Result of an Empirical Study”, dalam Jurnal Methods, Data, Analyses, Vol. 8 (1), 2014.

Zamakhsyarî. Abû Qasim Mahmud ibn Umar al-, al-Kasysyâf 'An Haqâiqi Ghamâmi al-Tanzîl wa 'Uyûn al-Aqawîl fî̀ Wujûh al-Ta'wîl, Beirut: Dâr al-Kutub al'Alamiyah, 2009.

Wawancara pribadi dengan Badriah (Penyuluh Agama Honorer), Bogor Selatan, Kota Bogor, 29 Mei 2015.

Wawancara pribadi dengan Oha (Ketua Majelis Taklim Darul Huda al-Hasanah), Bogor Selatan, Kota Bogor 7 Juni 2015.

Wawancara pribadi dengan Sussy Wijaya Drie Warsono (Ketua Majelis Taklim atTakwa), Bogor Selatan, Kota Bogor 2 Juni 2015.

Wawancara pribadi dengan Ade Mulyana (Ketua Majelis Taklim al-Barokah), Bogor Selatan, Kota Bogor, 29 Mei 2015. 